\title{
The Role of Leadership in Combating Corruption in Decentralized Governance Structures of Ghana: An Empirical Study of GA South District Assembly
}

\section{John K Asamoah*}

Department of Management, National Investment Bank, Accra, Ghana

\begin{abstract}
The study attempted to investigate how leadership can be used to combat corruption in decentralized governance structures of Ghana. In conducting the study, purposive sampling technique was employed to select key officials of GA south municipal assembly whose duties often promote corrupt practices. The questionnaire technique was the research instrument while a statistical package for social science was used to facilitate the analysis of data captured from the field. Findings of the study noted that under invoicing, over invoicing, payment for works not done among others are serious corrupt practices prevailing within the decentralized grassroots governance structures. It also came to light that political interference, appointing political operatives to key positions in governance units all promotes corrupt practices. The study noted that if political interference can be removed in the administration of these decentralized structures, effective leaders who are mainly technocrats can offer sound management framework for carrying out the developmental agenda of these decentralized structures. The study called on government of African countries to endeavour to finance the activities of political parties so as to remove the need for amassing wealth through fair or foul means for strengthen political structures to win elections. Strong leaders are required towards combating corruptions, however there is the need to ameliorate completely the effect of political interference in the administration of decentralized governance structures.
\end{abstract}

Keywords: Leadership; Corruption; Value-for money; Decentralization; Governance; Political authority

\section{Introduction}

Corruption is one menace which continue to be politicized in Ghana leading to its over decades. Political leaders often pride themselves with efforts at curbing its resurgence yet Ghana's position on the corruption perception Index (CPI) table only improve marginally. According to transparency international, the global organization in charge of CPI, Ghana's CPI for 2015 released in 2016 was 47 and this ranked the country $56^{\text {th }}$ out of 167 countries. Although this was lower than the 2014 mark, the ranking improved from $61^{\text {st }}$ to $56^{\text {th }}$ position. The CPI index of the country has fluctuated over the decade sending the signal that strategies adopted so far have been sustainable.

The politicization of this social vice is really counter fighting efforts at curbing the menace. The fact was confirmed by Kan-Dapaah [1] who noted that the first step towards genuinely fighting corruption in Ghana lies in refraining from politicizing issues of corruption. The source blamed the increase in corruption in public office at the doorsteps of parliament, the Judiciary and the Auditor-General. Members of Parliament especially those in the majority were fighting to catch the eye of the president for ministerial appointments or waiting for development project in the constituencies would never exercise their critical role of protecting the nations purse [1].

The head of the Judiciary and Auditor General are all appointees of the ruling political authorities and although there are stringent measures for uprooting corruption, these highly placed state officials do wish to be seen as offending the executive arm of state through incurring their displeasure over taking disciplinary measures against political appointees and other officials. In order to ensure fair distribution of national revenue government of Ghana has partitioned the country into 242 .

\section{Statement of the Problem}

Ghana's corruption perception index (CPI) has fluctuated over the years since 2008. Although the country's position on the world ranking somehow 2016, it scored only 47 points. This compares most unfavorably with other African countries like Botswana 63 and Rwanda 54 point (Asare-Boadu). According to Akomea political leaders in the country plot to create, loot and share the resources of the country. The source lamented over the fact during the election years Ghana blends from the wounds of corruption and that the country's resources are not properly leveraged to provide the much-needed infrastructure and social amenities for the citizenry.

The establishment of the Economic and organized Crime outfit (EOCO) to prosecute economic saboteurs nearly a decade ago has not helped matters since the operations of this corruption combating unit have been politicized so much that the government of the day picks and chooses who should undergo prosecution.

From the foregoing it is evident that the country has a serious problem with leadership in all fronts of political framework. The district Assembly have been established to facilitate speedy dispensation of governance to rural and sub-urban areas close to $7^{1} / 2 \%$ of the national revenue is channeled through these 216 decentralized administrative units which have been classified into metropolitan, municipal and district assemblies.

Development projects on health, education, infrastructure, etc are identified, brainstormed and executed by members of these Assemblies. Unfortunately, guidelines for awarding contracts under the auspices of

*Corresponding author: John K. Asamoah, Department of Management, National Investment Bank, Accra, Ghana, Tel: +233244294186; E-mail: jkwakuasamoah@gmail.com

Received September 25, 2017; Accepted November 02, 2017; Published November 17, 2017

Citation: Asamoah JK (2017) The Role of Leadership in Combating Corruption in Decentralized Governance Structures of Ghana: An Empirical Study of GA South District Assembly. Review Pub Administration Manag 5: 228. doi:10.4172/23157844.1000228

Copyright: () 2017 Asamoah JK. This is an open-access article distributed under the terms of the Creative Commons Attribution License, which permits unrestricted use, distribution, and reproduction in any medium, provided the original author and source are credited. 
the country's procurement laws are seriously flouted to the detriment of socio-economic growth of the people. Newspaper front pages continues to be inundated with reports of Metropolitan, Municipal and district chief executives and the finance and procurement directors embezzling funds meant for improving socio-economic systems of the down trodden. These decentralized agencies of governance lack effective leaders who will ignore pressure from political party members for contriving corruption stricken projects. Here-in lies the thrust of the study using GA South Municipal Assembly as the study.

\section{Objective}

The study examines how leadership can be employed to fight corruption which is endemic in the administrative fabric of Ghana's decentralized governance structure. Specific objective includes:

- To identify areas within decentralized governance structures where effective leadership is required to combat corrupts.

- To examine how leadership can be employed to curb corruption within the district Assembly system.

- To explore further strategies for using leadership to reduce political influence on decentralized governance system so as to minimize corruption in their operations.

- To identify challenges facing leadership of decentralized organizations in curbing corruption.

\section{Literature Review}

\section{Leadership concept}

Yukl [2] defines leadership as "the process of influencing others to understand and agree about what needs to be done and how to do it, and the process of facilitating individual and collective efforts to accomplish shared objectives". Northouse [3] defines leadership as "a process whereby an individual influence a group of individuals to achieve a common goal." These definitions suggest several components central to the phenomenon of leadership. Some of them are as follows: (a) Leadership is a process, (b) leadership involves influencing others, (c) leadership happens within the context of a group, (d) leadership involves goal attainment, and (e) these goals are shared by leaders and their followers. The very act of defining leadership as a process suggests that leadership is not a characteristic or trait with which only a few, certain people are endowed with at birth. Defining leadership as a process means that leadership is a transactional event that happens between leaders and their followers.

Viewing leadership as a process means that leaders affect and are affected by their followers either positively or negatively. It stresses that leadership is a two-way, interactive event between leaders and followers rather than a linear, one-way event in which the leader only affects the followers [4].

\section{Nature and traits of leadership}

With the needs of organizations keep changing Yukl [2] argues that the concept of leadership will also continue to evolve. The attitude and behaviors of leaders play an essential role in molding employee attitudes especially in terms of job satisfaction and commitment to the organization [5]. According to Kornor and Nardvik [6] different leaders behave in ways that are also different yet their success or otherwise could be a function of their follower's needs and the situation prevailing within the organization.
Leadership happens among people and usually involves the use of influence to attain goals. Influencing people imply that the relationship between leader and his people are not passive. Furthermore, influence has been made to attain some specific end or goal. So, when Fairhurt [7] defines leadership as the ability to influence people towards the achievement of goals then he captures the idea that leaders must be involved with other people in the attainment of results or goals.

In an attempt to distinguish leadership from management, Byrne argues that while leadership cannot replace management, the two are all required to meet organizational goals. The source explains that good management is required to help the organization to meet current commitments while good leadership is essential to move the company into the future.

\section{Theories of leadership}

Leadership is a widely researched management subject owing to its role in meeting organizational goals. Various theories have been put forward to attempt to explain how leadership facilitates management processes. Fiedler [8] and his associates, for instance made extensive efforts to combine leadership style and organizational situation. The basic idea in this contingency theory is that when one matches the leader's style with the most favorable situation, his or her success can be assessed. Friedler's contingency theory's cardinal factor has to do with the extent to which the leader's style is relationship or task oriented. It can be inferred that the contingency theory on leadership enjoins team leaders to take their assigned tasks seriously so as to come out as successful leaders. Leaders who also maintain good relationship with team-members should be on their way to become successful leaders. A good leader-member relationship emanates from instances where employees or team members trust, respect and have confidence in their leader. Task structure concerns the extent to which jobs conducted by the group are clearly defined with laid down procedures and have clearly cut goals. The next leadership theory worth discussing is the situational theory which according to Morgeson and Ilies [9] could be taken as behavioral theories. Co-researchers Hersey and Blanchard's have been credited with extensive findings on situational theory. The approach here throws a great deal of light on the characteristics of employees in determining the appropriate leadership behavior. People who tend to be low in task readiness because they are exposed to little ability or training and therefore appear less secured in their jobs. The last leadership theory is the path goal theory which according to Collins [5] is premised on the fact that the leader's responsibility involves increasing sub-ordinates motivation so as to encourage an earlier attainment of personal and organization goals. A leader could increase the motivation of staff or team members by facilitating the subordinate's path to the kinds of rewards that are available or strategies to increase the reward level that the team members or subordinates value and desire. Path here refers to the need for the leader to successfully guide the worker to identify and pick up behavioral patterns that will ensure successful completion of task [10]. Project Team leaders are therefore expected to lead their team members to adopt behaviors that should help the team to stay on course and attain the set goals.

\section{Leadership and management}

Leadership is similar to, and different from, management. They both involve influencing people. They both require working with people. Both are concerned with the achievement of common goals. However, leadership and management are different on more dimensions than they are similar. Barret [4] believes that managers and leaders are very distinct, and being one precludes being the other. He argues that 
managers are reactive, and while they are willing to work with people to solve problems, they do so with minimal emotional involvement. On the other hand, leaders are emotionally involved and seek to shape ideas instead of reacting to others' ideas. Managers limit choice, while leaders work to expand the number of alternatives to problems that have plagued an organization for a long period of time.

Leaders change people's attitudes, while managers only change their behavior. Mintzberg contends that managers lead by using a cerebral face. This face stresses calculation, views an organization as components of a portfolio, and operates with words and numbers of rationality. $\mathrm{He}$ suggests that leaders lead by using an insightful face. This face stresses commitment, views organizations with an integrative perspective, and is rooted in the images and feel of integrity. He argues that managers need to be two-faced. They need to simultaneously be a manager and a leader. Kotter [11] argues that organizations are over managed and under-led. However, strong leadership with weak management is no better and may be worse. He suggests that organizations need strong leadership and strong management. Managers are needed to handle complexity by instituting planning and budgeting, organizing and staffing, and controlling and problem solving. Leaders are needed to handle change through setting a direction, aligning people, and motivating and inspiring people. He argues that organizations need people who can do both they need leader-managers.

Rowe [12] contends that leaders and managers are different and suggests that one aspect of the difference may be philosophical. Managers believe that the decisions they make are determined for them by the organizations they work for and that the organizations they work for conduct themselves in a manner that is determined by the industry or environment in which they operate. In other words, managers are deterministic in their belief system. Leaders believe that the choices they make will affect their organizations and that their organizations will affect or shape the industries or environments in which they operate. In other words, the belief systems of leaders are more aligned with a philosophical perspective of free will. Organizations with strong management but weak or no leadership will stifle creativity and innovation and be very bureaucratic.

Conversely, an organization with strong leadership and weak or nonexistent management can become involved in change for the sake of change that is misdirected or meaningless and has a negative effect on the organization. Bennis and Nanus [13] expressed the differences between managers and leaders very clearly in their often-quoted phrase: "Managers are people who do things right and leaders are people who do the right thing". Implicit in this statement is that organizations need people who do the right thing and who do the "right things right".

\section{Leadership style and organizational performance}

Relationship between leadership style and organizational performance has been discussed often. Most research, according to FuJin et al. [14] showed that leadership style has a significant relation with organizational performance, and different leadership styles may have a positive correlation or negative correlation with the organizational performance, depending on the variables used by researchers. McGrath and MacMillan report that there is significant relationship between leadership styles and organizational performance. Effective leadership style is seen as a potent source of management development and sustained competitive advantage, leadership style helps organization to achieve their current objectives more efficiently by linking job performance to valued rewards and by ensuring that employees have the resources needed to get the job done. Michael [15] compares leadership style with the leadership performance in schools and enterprises, and found that leadership style had a significantly positive correlation with the organizational performance in both schools and enterprises.

Broadly speaking, Derue et al. [16] point out that, leadership performance is identical with organizational performance. Business management attributes their successes to leadership efficiency, that is, the leadership style of administrative supervisors has a considerable effect on the organizational performance. Collins [5] opine that when executives use their leadership style to demonstrate concern, care and respect for employees, it would increase interest of employees in their work and enable them to put up better performance, thereby affecting their job satisfaction positively. Fu-Jin et al. [14] also confirm that there is a positive relation between leadership style and organizational performance.

\section{Corruption in Africa}

Over the last few years, Mauro [17] argue that, the issue of corruption- the abuse of public office for private gain- has attracted both academicians and policy makers. Corruption scandals, as well as other reasons, have toppled governments in both major industrial countries and developing countries. According to Bissessar [18], corruption is dishonest or illegal behavior, especially by people in official positions, (misused power of the officials), while economists largely view corruption as a sand in the gear of the economy, political scientists view it as the grease in that gear. Positive effects of corruption can be looked at through the lens of the argument that corruption helps to overcome bureaucratic rigidities and helps maintain allocation efficiency when there is competition between bribers, but not between officials. Small side payments to officials could speed up bureaucratic processes and hence promote economic growth. Some justify corruption in the enforcement of property rights [19].

Calderisi [20] also lament that, certain illegal acts such as fraud, money laundering, drug trading, and black-market operations do not constitute corruption in and of themselves, because they do not involve the use of public power; however, those activities seldom thrive without widespread corruption because people who are involved in those activities must include public officials and politicians.

In the large literature on corruption in Africa, often overlooked is the issue that corruption became endemic and chronic after most nations gained independence. To bridge this gap, we focus on each individual African country and examine its historical record of changes in leadership and corruption since attaining independence. KanDapaah [1] indicates that Africa's corruption is a manifestation of its weak or bad governance, its undemocratic dictatorial leaderships, and its institutional ineptness post-independence.

Types of corruption: Three types of corruption can be identified in democratic societies.

Grand corruption: It generally refers to the acts of the political elite (selected officials) by which they exploit their power to make economic policies [21]. A corrupt political elite can change either the national policies or the implementation of national policies to serve its own interests at some cost to the populace; public spending is diverted to these sectors where gains from corruption are greatest; also, little attention is paid to whether the needs of the collectivity are served by those works or services [22]. This type of corruption is difficult to identify and measure especially when at least some segments of the population will gain. This type of corruption may have very serious consequences for a society. 
To study the link between this type of corruption and the cost of misdirected public policies is difficult because of the lack of precise measurements tools. However, the extreme situations of this type of corruption are somewhat easier to study where a dictator makes no distinction between his own wealth and that of the country or makes policy decisions that serve exclusively his own interests [23].

Bureaucratic corruption: This, in the opinion of Lawal [24] is the corrupt acts of the appointed bureaucrats in their dealings with either their superior (the political elite) or with the public. In its most common form, usually known as petty corruption, the public may be required to bribe bureaucrats either to receive a service to which they are entitled or to speed up a bureaucratic procedure. Corruption in the judiciary, where bribes can lower either the costs or the chances of legal penalties is another form of this type of corruption [25]. Models for this type of corruption have relied on equilibrium in markets for supply and demand of services which in turn leads to the analysis of costs and revenues associated with these services.

Legislative corruption: This refers to the manner and the extent to which the voting behavior of legislators can be influenced. Legislators can be bribed by interest groups to enact legislation that can change the economic rents associated with assets. This type of corruption would include "vote-buying" [25].

Causes of corruption: Corruption, in the view of Bissessar [18] is wide spread in developing countries, not because their people are different from people elsewhere but because conditions are ripe for it such as motivation to earn income is extremely strong due to; poverty, low salaries (wages), high risks of all kinds (illness, accidents and unemployment); (lack of insurance) etc. opportunities to engage in corruption are numerous, more regulations lead to higher opportunities for corruption:

- Weak legislative and judicial systems.

- Law and principles of ethics are poorly developed.

- Population relative to natural resources is large.

- Political instability and weak political will.

Effects of corruption: One can summarize the consequences of corruption as follows:

- Lower investment, including foreign direct investment.

- Reduced Economic growth.

- A shift in the composition of government spending from more productive to less productive activities.

- Greater inequality and high incidence of poverty.

- Reducing the efficiency of aid.

- Exposing the country to currency crises.

Combating strategies for corruptions: To approach the question of how to combat corruption, it would be worthwhile laying out a framework that brings together economic and noneconomic factors. Mauro [17] points out the difficulties of fighting widespread corruption; he refers to strategic complementarity "where if one agent does something, it becomes more profitable for other agent to do the same." The economic approach to preventing or at least limiting corruption consequences is by responding to the economic causes of corruption [26]. As such, the approach does not seek quick remedies, but, by focusing on fundamental economic growth, tends to bring about conditions where corruption is minimized. Omani-Boamah [27] reveal that, one of the root causes of corruption is the presence of heavy government intervention which is reflected in excessive and complex regulations and a high tax and tariff rates. One of the first tasks in the war against corruption must therefore be the rationalization of the role of the government in the economy.

\section{Research Methodology}

This segment outlines the details of the research methodology. It commences by disclosing the research design, population of the study, sampling technique, research instrument, administration of research instrument and data analysis.

\section{Research design}

Taking cognizance of the fact that the objectives of the study could be achieved through questions and answers, the study adopted the sample survey research design the quantitative research approached helped in soliciting the relevant information from the study area.

\section{Population of the study}

GA south municipal assembly was the study area were primary data was obtained from public servants within such departments as finance, procurement, HR, projects, budgeting, building inspectorate etc. most of these personnel were sympathetic to the study because they seem to be tired to the kind of funds that politicians stash away from their outfit for political activities. In all 95 officials were slated as respondents for the study yet 84 positively responded to the study.

\section{Sampling procedure}

The study interviewed officials of all functionaries within GA south municipal assembly. Since, not all officials could grant the required information for meeting the objectives of the study, it was necessary to use purposive sampling technique for soliciting views. This ensured that all relevant and key personnel have been covered for their views on the study.

\section{Research instruments}

The questionnaire technique was adopted as the research instrument. The choice was informed by the fact that it enabled respondents to use their leisure periods co-operate with the study. Marczyk et al. [28] are also of the conviction that, the questionnaire technique affords an enlightened respondent the opportunity of employing their leisure periods especially in the comfort of their homes or offices to assist a research or an investigation.

\section{Administration of research instrument}

A time frame not exceeding two weeks was given to prospective respondents to honour the questionnaires. At intervals, the researcher kept reminding the interviewees of their responsibility to the study. The researcher personally went around to pick up the answered "scripts". Care was exercised to ensure that all areas had been filled except where they did not apply to the respondent. Respondents who also sensed their limitation in answering certain questions were helped by the researcher.

\section{Data analysis}

The Statistical Package for Social Science (SPSS) was used to facilitate the analysis of data and the resulting tables and figures have been presented in the next paragraph. 


\section{Data Presentation and Analysis}

Results in respect of information captured from the field have been presented and analyzed in the following paragraphs. Perhaps it might the worth noting that, these have been arranged in consonance with the order of specific of the objectives.

Issues relating to identifying areas within decentralized structures where effective leadership is required to combat corruption

Discussed here are the nature of corruption in decentralized governance structures as well as areas within these governance systems where leadership can be used to combat the menace.

Views on how corruption presents on the decentralized governance structure: Results of the manner in which corruption is perpetuated within the governance decentralized systems of Ghana have been presented in Table 1.

It can be gathered from Table 1 that over invoicing ranks first with the mean score of 4.08 and standard deviation of 0.471 . The smaller the standard deviation suggests the accuracy of the statement in relation to the objective under consideration. Since the highest quantum within the Likert scale is 5 and over invoicing scored 4.08 , it presupposes that a good number of respondents shared the view that one of the most essential corrupt practices damaging the operations of decentralized, grassroots governance structures is over invoicing. In the opinion of Aziz [29], equipments and other materials supplied to strengthen service delivery have their prices inflated so badly that sometimes public funds pay as much as double the normal price of these facilities. Dishonest government officials and suppliers often share the difference in price as their booty. Ranking second with a mean score of 4.07 and standard deviation of 0.597 is the statement that corruption in public institutions also presents in the form of under invoicing. A typical examine of under invoicing according to Anku [30] presents in situations where public assets especially vehicles and other unserviceable equipments, which have had their utility optimized and for that matter ought to be disposed off. Here, the public officer colludes with the auctioneer and sells the equipments to themselves at ridiculously low prices so as to enable them resell almost immediately at huge profit. In such circumstances, officials enrich themselves at the expense of public purse.

The corrupt practice of siphoning public materials for private use came third with a mean score of 4.00 and standard deviation of 0.538. In such circumstances, Baneseh [31] note that building materials procured and stored for public rehabilitation projects are diverted to build private dwelling homes or in some cases even sold for personal gains. The danger here according to this source is that public offices and building can hardly be rehabilitated thereby leaving them in dilapidated state. The fourth ranking, with the mean score of 3.93 and standard deviation of 0.803 , went to the statement that public funds received for use within the metropolitan, municipal and district assemblies are shared by a syndicate of public officials and sometimes aided by external politicians and lodged into their private accounts. This way, developmental projects can hardly be accomplished leading to a good number of uncompleted projects scattered within the communities.

The statement that corrupt practices within the decentralized governance unit also take the form of making payment for goods not supplied had a mean score of 3.64 and standard deviation of 0.9. This in most case according to Kan-Dapaah [1] is perpetuated by the officials of the procurement department in connivance with the

\begin{tabular}{|c|c|c|c|c|}
\hline Statement on nature of corruption & $\begin{array}{c}\text { Sample } \\
\text { size }\end{array}$ & $\begin{array}{c}\text { Mean } \\
\text { square }\end{array}$ & $\begin{array}{c}\text { Standard } \\
\text { deviation }\end{array}$ & Variance \\
\hline Over invoicing for personal gains & 84 & 4.08 & 0.471 & 0.222 \\
\hline Under invoicing for private gains & 84 & 4.07 & 0.597 & 0.356 \\
\hline $\begin{array}{c}\text { Siphoning public materials for private } \\
\text { use }\end{array}$ & 84 & 4.00 & 0.538 & 0.289 \\
\hline $\begin{array}{c}\text { Diverting public funds into private } \\
\text { accounts }\end{array}$ & 84 & 3.93 & 0.803 & 0.645 \\
\hline $\begin{array}{c}\text { Promoting unqualified staff for private } \\
\text { gains }\end{array}$ & 84 & 3.86 & 0.747 & 0.558 \\
\hline $\begin{array}{c}\text { Using state funds to finance private } \\
\text { political activities }\end{array}$ & 84 & 3.79 & 0.945 & 0.893 \\
\hline $\begin{array}{c}\text { Granting contracts to unqualified } \\
\text { people for private gains }\end{array}$ & 84 & 3.71 & 0.886 & 0.785 \\
\hline $\begin{array}{c}\text { Making payment for goods not } \\
\text { supplied }\end{array}$ & 84 & 3.64 & 0.9 & 0.811 \\
\hline Authorizing payment for contracts not \\
executed
\end{tabular}

Source: Field data in 2017.

Table 1: Frequency table on nature of corruption in Ghana's decentralized governance system.

\begin{tabular}{|c|c|c|c|c|}
\hline $\begin{array}{c}\text { Statement on areas which require } \\
\text { effective leadership }\end{array}$ & $\begin{array}{c}\text { Sample } \\
\text { size }\end{array}$ & $\begin{array}{c}\text { Mean } \\
\text { square }\end{array}$ & $\begin{array}{c}\text { Standard } \\
\text { deviation }\end{array}$ & Variance \\
\hline Procurement department & 84 & 4.07 & 0.538 & 0.289 \\
\hline Human resource directorate & 84 & 4.00 & 0.889 & 0.089 \\
\hline Budgets and monitoring & 84 & 3.86 & 0.747 & 0.558 \\
\hline Building inspection & 84 & 3.79 & 0.945 & 0.893 \\
\hline Trade / Business licensing unit & 84 & 3.79 & 0.777 & 0.604 \\
\hline Finance department & 84 & 3.79 & 1.019 & 1.038 \\
\hline Projects monitoring & 84 & 3.71 & 0.886 & 0.785 \\
\hline Protocol & 84 & 3.64 & 0.9 & 0811. \\
\hline Presiding membership & 84 & 3.57 & 1.185 & 1404 \\
\hline Revenue collection sub-units & 84 & 3.5 & 0.988 & 0.976 \\
\hline
\end{tabular}

Source: Field data in 2017.

Table 2: Frequency on areas which requires effective leadership in decentralized governance.

external suppliers. This also, the source explains, gravely adversely affects not only the financial position but also the service delivery ability of such governance unit. The corrupt practice of unscrupulous officials authorizing payment for works contracts not executed had a mean score of 3.57 and standard deviation of 0.909 . Another disturbing trend of corrupt practice within the decentralized public service has to do with taking bribes prior to granting license for various purposes. It also came to light that, some officials in charge of collecting internally generated funds (IGF) often pocket huge portion of these important revenue to the detriment of public goods.

Views on issues concerning areas in decentralized governance structures that require effective leadership to combat corruption: Data on the above objective of the study have been shows on Table 2. It is clear from Table 2 that one important area which requires effective leadership in the grassroots government structures is the procurement department. This had a mean score of 4.07 and standard deviation of 0.889 . This is not surprising especially where most of the corrupt 
practices such as over invoicing, double payment, diversion of building materials etc all take place [32]. The procurement department also has a hand in works contract and for that matter getting an effective leader will ensure that most of these corrupt practices are reduced drastically. Ranking second with a mean score of 4.00 and standard deviation of 0.538 is the statement that the HR department also controls a lot of cash resources especially those that relate to staff cost. An ineffective leader often compromises his position and allows ghost names to infiltrate the wage sheet leading to serious losses to the grassroots unit.

Ranking third with a mean score of 3.86 and standard deviation of 0.747 with regards to areas where good leaders are required in the decentralized structures is the budget and monitoring departments where financial planning, projections are controlled to enhance the administrative set up of these grassroots governance units. Inflation of project cost according to Yukl [2] and other corrupt practice emanate from this sector. A further area where the study noted that effective leadership is necessary lies with the issuance and renewal of business licensing and permit. Here, field officers connive with their supervisors and make away with a chunk of funds which ordinarily should have been routed through the organizations' coffers. One key area for generating funds for the up keep of the decentralized structures lies with registration of businesses fees and renewal of permits on annual basis. If adequate measures were taken to ensure that good leaders are positioned in the helm of affairs, then these governance units will be on the way towards gaining enough funds for their operations without having to always fall on central government for assistance.

More often than not, brainstorming sessions for projects prioritization at conducted at the assemblies where the presiding elders command some special powers. The statement on the need for having an effective leader as a presiding member had a mean score of 3.57 and standard deviation of 1.185. Effective leaders performing the role of presiding elders will ensure that value for money procurement activities are embarked upon. The study also noted that the revenue collection sub unit all require good leaders with strong will who will resist attempt at negotiations for sharing i.e. stealing substantial portions of revenue collected.

\section{Analysis of issues relating to how leadership can be employed to curb corruption within district assemble}

Results on how effective leadership can be used to reduce corruption within district, municipal and metropolitan assemblies have been shown in Table 3 .

Presented in Table 3 are statements in respect of how leadership can be used to reduce corrupt practices in the decentralized structures of governance in Ghana. Ranked first with mean score of 4.21 and standard deviation of 0.561 is the statement that the corrupt practices can be greatly ameliorated by placing qualified professional at key places especially finance, procurement, HRM, revenue collection etc. Ranking second with mean score of 4.08 and standard deviation of 0.417 is the statement that corrupt practices can be reduced if departmental heads were exposed to regular capacity building sessions in leadership and patriotism etc. Minimizing political influence in award of contracts in various functionaries of decentralized governance system was ranked third with a mean score of 4.07 and standard deviation of 0.597 . A further strategy for using leadership to contain corrupt practices in grassroots governance has to do with exposing civil and public servants within such district offices to proper remuneration. The study also noted that minimizing corrupt practices within the decentralized structures entail ensuring that key officials declare their assets at least once a year.

\begin{tabular}{|c|c|c|c|c|}
\hline $\begin{array}{c}\text { Statement on use of affective } \\
\text { leadership to curb corruption }\end{array}$ & $\begin{array}{c}\text { Sample } \\
\text { size }\end{array}$ & $\begin{array}{c}\text { Mean } \\
\text { square }\end{array}$ & $\begin{array}{c}\text { Standard } \\
\text { deviation }\end{array}$ & Variance \\
\hline $\begin{array}{c}\text { Placing qualified professional at key } \\
\text { places especially finance, procurement, } \\
\text { HRM, revenue collection etc. }\end{array}$ & 84 & 4.21 & 0.561 & 0.315 \\
\hline $\begin{array}{c}\text { Exposing departmental head to regular } \\
\text { capacity building sessions in leadership } \\
\text { and patriotism etc. }\end{array}$ & 84 & 4.08 & 0.417 & 0.222 \\
\hline $\begin{array}{c}\text { Minimizing political influence in award } \\
\text { of contracts in various functionaries of } \\
\text { decentralized governance system. }\end{array}$ & 84 & 4.07 & 0.597 & 0.356 \\
\hline $\begin{array}{c}\text { District, municipal, metropolitan chief } \\
\text { executives should be barred from } \\
\text { contesting as parliamentarians for the } \\
\text { areas they serve. }\end{array}$ & 84 & 4.00 & 0.538 & 0.289 \\
\hline $\begin{array}{c}\text { Heads of decentralized units need not } \\
\text { be appointed by the political authorities. } \\
\text { The position should be by election. }\end{array}$ & 84 & 3.93 & 0.889 & 0.645 \\
\hline $\begin{array}{c}\text { Civil and public servants within } \\
\text { such district offices should be well } \\
\text { remunerated. }\end{array}$ & 84 & 3.93 & 0.803 & 0.79 \\
\hline $\begin{array}{c}\text { Ensuring that key officials within the } \\
\text { decentralized system declare their } \\
\text { assets at least once a year. }\end{array}$ & 84 & 3.79 & 0.945 & 0.893 \\
\hline Source: Field data in 2017 . & & & \\
\hline
\end{tabular}

Source: Field data in 2017

Table 3: Frequency table on how leadership can be used to minimize corruption in decentralized governance system in Ghana.

\begin{tabular}{|c|c|c|c|c|}
\hline $\begin{array}{l}\text { Statement on further strategies for } \\
\text { combating corruption }\end{array}$ & $\begin{array}{l}\text { Sample } \\
\text { Size }\end{array}$ & $\begin{array}{l}\text { Mean } \\
\text { Square }\end{array}$ & $\begin{array}{l}\text { Standard } \\
\text { deviation }\end{array}$ & Variance \\
\hline $\begin{array}{l}\text { Decentralized governance structure } \\
\text { should not be used as dumping grounds } \\
\text { for foot soldiers of political parties who } \\
\text { win power. }\end{array}$ & 84 & 4.07 & 0.597 & 0.356 \\
\hline $\begin{array}{l}\text { Works and supply contracts should not } \\
\text { be awarded based on instructions from } \\
\text { highly placed political figures. }\end{array}$ & 84 & 3.86 & 0.838 & 0.702 \\
\hline $\begin{array}{l}\text { The state should fund activities of } \\
\text { political parties so as to remove the } \\
\text { need to direct their funding requirement } \\
\text { at the decentralized governance } \\
\text { structure. }\end{array}$ & 84 & 3.86 & 0.643 & 0.413 \\
\hline $\begin{array}{l}\text { Government should intensify efforts at } \\
\text { empowering the private sector to create } \\
\text { more jobs so as to pre-empt the urge to } \\
\text { use membership of political party as job } \\
\text { seeking avenue. }\end{array}$ & 84 & 3.64 & 0.977 & 0.955 \\
\hline $\begin{array}{l}\text { Generally, there is the need to } \\
\text { conscientize the youth and adolescent } \\
\text { against the crazy for quick wealth which } \\
\text { breeds corruption at all fronts especially } \\
\text { in the decentralized political structures. }\end{array}$ & 84 & 3.36 & 1.453 & 2.112 \\
\hline
\end{tabular}

Source: Field data in 2017.

Table 4: Frequency table on reducing political interference in leadership to curb corruption at decentralized governance.

Northouse [3] is of the view that when officers at the various stages of governance are made to declare their assets periodically, it will minimize the desire to amass wealth thereby embarking upon corrupt practices. Morgeson [9] also spoke of exposing of officers of the decentralized structures to sound emoluments. According to the source paying them well will pre-empt any corruption tendencies thereby protecting public purse for improving service delivery to enhance the living standards of the people.

Further strategies for reducing political interference so as to employ leadership to curb corruption at decentralized governance systems

Presented in Table 4 are statements on how political interference 
can be removed from the governance system so as to employ leadership to reduce corrupt practices. Ranking first with a mean score of 4.07 and standard deviation of 0.597 is the statement that decentralized governance structure should not be used as dumping grounds for foot soldiers of political parties who win power. Ranked second with a mean score of 3.86 and standard deviation of 0.838 was the statement that works and supply contracts should not be awarded on the basis of instructions from highly placed political figures. This often creates room for corrupt practices because, according to Aziz [29] such outside instructions come with specified quantity bills which are often inflated and meant to align the pockets of a few selfish and scrupulous individuals. The statement that the state should finance activities of political parties so as to remove the need to direct their funding requirement at the decentralized governance structure was ranked another second with a mean score of 3.86 and standard deviation of 0.643. This, Anku [30] explains will help minimize the edge to pile up funds in order to finance political party activities. This presupposes that, when a state finances political parties, incidence of over invoicing and payment for works not done etc will all be minimized.

Ranking fourth with a mean score of 3.64 and standard deviation of 0.977 was the statement that government should intensify efforts at empowering the private sector to create more jobs so as to pre-empt the urge to use membership of political party as job seeking avenue. The statement that there is the need to conscientize the youth and adolescent against the crazy for quick wealth which breeds corruption at all fronts especially in the decentralized political structures was ranked fifth with the mean score of 3.36 and standard deviation of 1.453. The need for counseling the youth against "get rich quick attitude" is timely since a good number of have resorted to even using devilish spiritual means to acquire wealth. Government in the opinion of Baneseh [32] should strengthen the arms of the private sector to create more jobs for the youth. This can be done through the acquisition of concessionary rated loans for the benefit of enterprises.

\section{Analysis of issues relating to challenges facing leadership of decentralized organization in curbing corruption}

Data on challenges facing decentralized institutions in using leadership to curb corruption have been presented in Table 5 .

Presented in Table 5 are the challenges facing leaders decentralized governance structures in reducing corrupt practices. Ranking first with a mean score of 4.21 and standard deviation of 0.561 is the statement that political interference in the award of works contracts is the worst challenge to leaders of decentralized governance structures in combating corruption. Ranked second with a mean score of 4.08 and standard deviation of 0.538 was the idea that ruling political party determining how budget should be spent also compromises on the integrity of leadership in the district assemblies. In the opinion of Kan-Dapaah [1] such budgetary provisions are often inflated in respect of works and supply contracts. The statement that rivalry between parliamentarian and head of decentralized units constituted a huge challenge to leadership of district assemblies, was ranked third with a mean score of 4.07 and standard deviation of 0.471 .

The rivalry often stems from the fact that the local governance leaders often aspire to dislodge the parliamentarians in parliament and for that matter will attempt to block any project that is likely to brighten the prospect of the parliamentarian regaining his position in parliament. The Member of Parliament, with this at the back of his mind will also operate in such a manner that funds meant for the assembly is delayed in order not to give to the assembly leader an edge

\begin{tabular}{|c|c|c|c|c|}
\hline $\begin{array}{c}\text { Challenges negating using } \\
\text { leadership to curb corruption }\end{array}$ & $\begin{array}{c}\text { Sample } \\
\text { size }\end{array}$ & $\begin{array}{c}\text { Mean } \\
\text { square }\end{array}$ & $\begin{array}{c}\text { Standard } \\
\text { deviation }\end{array}$ & Variance \\
\hline $\begin{array}{c}\text { Political interference in the award of } \\
\text { works contracts. }\end{array}$ & 84 & 4.21 & 0.561 & 0.315 \\
\hline $\begin{array}{c}\text { Ruling political party determining how } \\
\text { budget should be spent. }\end{array}$ & 84 & 4.08 & 0.538 & 0.289 \\
\hline $\begin{array}{c}\text { Rivalry between parliamentarian and } \\
\text { head of decentralized units. }\end{array}$ & 84 & 4.07 & 0.471 & 0.22 \\
\hline $\begin{array}{c}\text { Inadequate emoluments for staff. } \\
\text { Heads of decentralized unit trying to } \\
\text { please God fathers in the political party. }\end{array}$ & 84 & 4.00 & 0.597 & 0.356 \\
\hline $\begin{array}{c}\text { The need to contribute to strengthen } \\
\text { the Financial base of the ruling political } \\
\text { party. }\end{array}$ & 84 & 3.71 & 0.886 & 0.785 \\
\hline $\begin{array}{c}\text { Demand made on heads by foot } \\
\text { soldiers of the ruling political party. }\end{array}$ & 84 & 3.43 & 1.122 & 1.260 \\
\hline $\begin{array}{c}\text { Society, family expectation from the } \\
\text { heads of decentralized units. }\end{array}$ & 84 & 3.29 & 1.036 & 1.074 \\
\hline Source: Field data in 2017. & & & & \\
\hline
\end{tabular}

Table 5: Frequency table on difficulty in using leadership to curb corruption at decentralized governance structures in Ghana.

over him. Such a rivalry often works inimical in the interest of the local people. The study noted further that demand made on heads of district assemblies by foot soldiers of the ruling political party often disrupt financial provisions for enhancing operations within the decentralized grassroots structures.

It also came to light that pressure from society especially family members' expectations from heads of decentralized units often promotes corrupt practices. Such an unfortunate eventuality according to Kan-Dapaah [1] has tribal connotations. In certain tribes, an ascension to public offices indicates that one should be in a position to cater for a broad spectrum of children within the school going age. Family members will therefore expect monthly stipends and other periodic payments for the up keep of their children. It is only by embarking upon corrupt practices that such external financial demand can be met.

\section{Discussion}

It came out unequivocally from the study that it takes a strong leader with good conscience and moral uprightness to discourage corrupt practices in developing economies especially in Africa. This conclusion was also made by Bissessar [18] in a similar study and revealed that people in political authority often twist the arm of public servants and in the process, get them to bend the rules in their favour. Corruption prevailing within decentralized governance structures as found by the study relates to over and under invoicing to serve the official's parochial interest. With regards to over invoicing, Lawal [24] also pointed out that prices of items procured are inflated in such a way that the supplier and the dishonest public officers share the difference in price to the detriment of the organization's finances. This, Kan Dapaah [1] mentioned, in his study as constituting one of the greatest patterns of corruption in the public sector. The source noted further that some officials in government institutions form a syndicate for perpetuating such dishonest practices. In a similar study on corruption in public institutions within the West African sub region, Aziz [29] noted that under invoicing in most public institutions occur when assets, being disposed off, are deliberately given away at lower price than the certified values. The officials supervising the auction process liaises with the auctioneer to pick up and share the under-valued component of the price leading to serious losses to the governments [29].

Reacting to the seriousness of inventory based corruption in public 
establishments, in their study on "white colour" corruption in public places, Gupta et al. [33] lamented over the fact that some syndicates in the public system organize and pay for equipments that are hardly supplied to the public office. Anku [30] also added from studies on public sector corruption that in some cases, equipment in stock are actually taken out and re-supplied for payments. Such incredible practices are successful because patriotic leaders are non-existent and moreover civil servants often complain of unrealistic salary levels [34].

On his part, Yukl [2] did not understand why in most developing economies especially in Black Africa corruption assume unreasonable proportion during electioneering campaign periods where most ruling governments capitalize on the incumbency advantage. This, Aziz [29] notes often takes the form of political chief executives making financial contributions directly to the political party and also giving inflated contracts to party members for very obvious reasons. Other forms of corruption such as allowing only party-card bearing officials of decentralized organs of governance to attend capacity building programs and educational tours outside the country are yet to be mentioned in existing literature on the subject of corruption. These therefore constitute the contributions that the study seeks to make to the body of knowledge in this domain of the academia.

The study did seek to investigate areas within the decentralized governance system where leadership was required to combat corruption. Findings pointed to areas such as HR directorate, procurement departments, budgets and monitoring, sanitation and building inspectorate as well as trade licensing unit as potential areas in their governing system where strong leadership framework is required. Fualin et al. also found out in their study on corruption in public places that governance units within the African sub-regions require strong leadership so as to make these outfits function as anticipated. During his maiden visit to Africa in 2010 president Obama of the USA called on Africa governments to ensure strong leadership to enable their institutions function properly.

The then USA head of state expressed surprise at the way drug peddlers manage to scale through with the contraband goods at the African Airport only to be arrested and incarcerated in American and European prisons. He bemoaned the poor governance leadership structure within the sub-region and advised the powers that be, to endeavour to reverse this unhealthy trend. He noted that the US was ready to help Africa build the much-needed transformational leaders.

On strategies for curbing corruption on decentralized governance system in developing economies, the study agreed with Aziz [29] that placing qualified professionals at key positions especially in finance, procurement, revenue collection etc will help curb the surge of corruption in the sub region. Regular training of departmental heads builds their capacity in leadership and virtues of patriotism. Answering a question put to him by South African journalist on the merits of African leaders planning to pull out of International Criminal Court (ICC) in July 2017, president Trump of the USA lamented over the lack of leadership qualities of Africa heads who shamelessly stash away the financial resources of their respective countries into their foreign accounts thereby worsening poverty levels on the continent. He retorted that Africa leaders "can't lead by example, they are only interested in accumulating wealth from poor tax payers".

\section{Conclusion}

The study examined how leadership can be leveraged in decentralized governance structures of Ghana so as to curb the canker of corruption which continues to disrupt service delivery at these outfits. The study saw under and over invoicing, diversion of public funds, strategically positioning political operatives at sensitive places as well as awarding supply and works contracts to cronies and friends as the form in which corruption permeates in these decentralized governance structures. It is conclusive that if strong well qualified, experienced managers were appointed to lead functionaries like HR directorates, procurement department, budgets and monitoring, building inspection unit as well as business licensing departments of these decentralized structures, appreciable gains can be made in the fight against corruption in the public service system.

This way procurement, recruitment and other functions of decentralized grassroots structures can be effectively shielded from political interference. The effect of the latter can further be ameliorated if appointments to positions of chief executives of the units were made elective rather than being the sole prerogative of the political leaders of the country. Corruption could further be considerably abated if top executives of the decentralized structures were barred from contesting parliamentary seats in areas where they operate. The existing arrangement puts pressure on these executives to amass wealth so as to unseat the incumbent parliamentarian. Generally, the study is of the view that the state should fund political party activities so as to remove the need to siphon state fund through corrupt practices for building political party structures. All these require strong leadership at all tiers of governance.

\section{Future Prospects}

A study ought to be conducted to investigate how political interference can be minimized if not eradicated completely from the governance of the decentralized system. The study stumbled on political interference as a huge force that promotes corrupt practices within the structures of governance in Ghana. It is even becoming increasingly clear that some strong leaders even bow to pressure from the political authority because of fear of losing jobs or being recycled within the public service. Certainly, government influence on the operations must be minimized. Technocrats must be allowed to perform, and this presupposes that a study ought to be conducted to explore the modalities for disengaging political authorities active involving in the administrative machines of these decentralized units of governance. The electoral commissioner, the chief justices are positions that are appointed by the government of the day, yet the constitution of the Ghana grants them some insulation from political machinations. Some studies here will help to structure the grassroots governance in a way as to enable the virtues of leadership to promote productivity.

\section{References}

1. Kan DA (2016) Let's not politicize fight against corruption, Daily Graphic, Ghana.

2. Yukl G (2006) Leadership in organizations. Upper Saddle River, NJ: PrenticeHall, USA

3. Northouse PG (2001) Leadership: Theory and practice, (2nd edn). Thousand oaks, C.A Sage, USA.

4. Barrett DJ (2006) The Definition of and model for leadership communication are based on this book. Leadership communication. McGraw-Hill, New York, USA

5. Collins J (2001) Level 5 leadership- The Triumph of humility and fierce resolve Harvard Business Review 67-76.

6. Kornor $\mathrm{H}$, Nardvik $\mathrm{H}$ (2004) Personality traits in leadership between the Scandiuwanim. J Psychol 45: 49-54.

7. Fairhust GT (2007) Discursive leadership: In-conversation with leadership psychology. Thousand Oaks, C.A Sage, USA. 
Citation: Asamoah JK (2017) The Role of Leadership in Combating Corruption in Decentralized Governance Structures of Ghana: An Empirical Study of GA South District Assembly. Review Pub Administration Manag 5: 228. doi:10.4172/2315-7844.1000228

Page 9 of 9

8. Fiedler FE (1974) Leadership and effective management, Glenview Scott Foresman, USA.

9. Morgeson FP, Ilies R (2007) Correlations between leadership traits and leadership styles. Unpublished Raw Data. Michigan State University, East Lansing, MI.

10. Ngodo OE (2008) Procedural justice and trust: The link in the transformational leadership-organizational outcomes relationship. Int J Lead Stud 4: 82-100.

11. Kotter JP (1990) A force for change: How leadership differs from management. New York: Free Press, USA.

12. Rowe WG (2001) Creating wealth in organizations: The role of strategic leadership. Acad Manage Perspect 15: 81-94.

13. Bennis W, Nanus B (2007) Leaders. The strategy for taking charge. New York. Blakely, USA.

14. Fu-Jin W, Shieh C, Tang M (2011) Effect of leadership style on organizational performance as viewed from human resources management strategy. Afr J Bus Manage 4: 3924-3936.

15. http://ala-apa.org/newsletter/2010/06/08/spotlight/

16. Derue DS, Nahrgang JD, Wellman N, Humphrey SE (2011) Trait and behavioral theories - Of leadership: an integration and meta-analytic test of their relative validity. Pers Psychol 4: 7-52.

17. Mauro $P$ (2002) The persistence of corruption and slow economic growth International Monetary Fund Working Paper Wp/02/213.

18. Nicole B (2009) Does corruption persist in Sub-Saharan Africa? Int Adv Econ Res 15: 336-350.

19. Frank V (2004) Taking corruption out of global business levels the field for U.S. Companies, World Trade Magazine.

20. Robert C (2006) The trouble with Africa: Why foreign Aid isn't working, New York: Palgrave Macmillan, USA. 3: 556-557.
21. Jain AK (2001) Corruption: A review. J Econ Sur 15: 71-121.

22. Cheryl GW, Kaufmann D (1998) Corruption and development. Financ Dev 35 7-10.

23. Klitgaard R (1998) International cooperation against corruption. Finance Development 35: 3-6.

24. Lawal G (2007) Corruption and development in Africa: Challenges for politica and economic change. J Hum Soc Sci, 2: 1-7.

25. Ackerman RS (1999) Corruption and government: Causes, consequences, and reform, Cambridge: Cambridge University Press, UK.

26. Bardhan $P$ (1997) Corruption and development: A Review of issues. J Econ Lit 35: $1320-1346$.

27. Boamah OE (2016) Ghana commended for fight against corruption, Daily Graphic, Ghana.

28. Marczyk GR, DeMatteo D, Festinger D (2005) Essentials of research design and methodology, New York City, NY: Wiley, USA.

29. Aziz A (2016) Fight against corruption: NPP Chastises NDC Government, Daily Graphic, Ghana.

30. Anku FP (2016) Adopt innovative measures in revenues collection, Daily Graphic, Ghana.

31. Baneseh MA (2017) Ofori-Atta responds to CHRAJ, Daily Graphic, Ghana.

32. Jafaru YM (2016) Former local government director ordered to return official vehicle, Daily Graphic, Ghana.

33. Gupta S, Davoodi M, Trongson E (2000) Corruption and provision of health care and education services. In Jain (2000) Forthcoming.

34. Mahama J (2016) Ghana on right path to fight corruption, Daily Graphic, Ghana 